\title{
COLLECTION AND ENFORCEMENT OF STATE CONSUMPTION EXCISE TAXES
}

\author{
Joseph W. Huston* and John R. Berrymant
}

The problem of collecting and enforcing taxes arises from the fact that they are not self-enforcing; the mere existence of provisions in a statute book is only an authorization for a flow of money into the public treasury. Not until persons with legal authority to compel observance of the statute analyze its provisions, study its authorizations and limitations, and then enforce its terms does it become more than a list of words in a book.

The tax administrator is concerned only with the most effective employment of available means for achieving the end of adequate tax collections under the statute he administers. Of no moment to him are the social effects of his tax law. That is the legislator's concern, as it is the concern of the judiciary that both taxpayer and administrator observe the law. ${ }^{1}$ The administrator's means for realizing the desired end are three. They are (r) the application of legal devices available for enforcing compliance, (2) the disposal of personnel and regard for "economic" factors affecting collections, and (3) the conduct of public and taxpayer relations. It is the purpose of this article to examine these means and to attempt an evaluation of them. Since nearly all tax administrators are faced with the problem of what "is" rather than what "should be," the distinction between theoretically perfect conditions and actual, less than perfect conditions is kept in mind throughout.

\section{Application of Legal Devices}

All tax laws contain legal devices designed to enforce compliance with their provisions. Any one of them is useful only in limited situations. The good tax law will therefore contain different "tools" for different situations, and the good tax administrator will use all the tools provided in the statutes to handle the various cranky col-

*A.B., 1929, Drake University. Supervisor, Division of Research and Statistics, Illinois Department of Finance. Co-author (with John R. Berryman), The A-B-C of Iluinors State Finance (2d ed. 1940); (with Thomas L. Smith), Toward Effective Tax Collections-Factors Determining tHe Completeness of Collection of State Consumption Excise Taxes (in press). Author of various legal articles on taxation.

+A.B., 1937, Amherst College. Assistant Supervisor, Division of Research and Statistics, Illinois Department of Finance. Co-author (with Joseph W. Huston), The A-B.C of Iluinors Stute FinsncB (2d ed. 1940).

${ }^{1}$ Since it is only rarely that the judiciary has to deal with a case in which public revenues are endangered by an administrator's action, the real function of the courts is to act as an "umpire" in disputes arising between the administrator and taxpayers. 
lection problems which inevitably arise. A brief review of the various tools made available by legislatures to tax administrators is thus in order.

Penalty provisions are the most common legal devices available for enforcement of consumers' excise taxes. They are of two types: civil penalties, usually in the form of a flat percentage addition to the tax upon failure to comply with the law, and criminal penalties, in the form of fine or imprisonment. Often, in addition to the civil penalty, provision is made for interest at the rate of one-half or one per cent per month for each month that the tax remains unpaid.

Penalty provisions are essentially devices to keep the rank and file of taxpayers "in line." The civil type constitute a mild form of economic coercion impelling the solvent and law-abiding taxpayer to eschew laxity in computing and paying his taxes. They may be looked upon as interest exacted by the state for failure to pay taxes by the date provided by law and as compensation for such trouble as the state may have to take to compel the payment of money rightfully owing to it. Viewed in this light, it would appear that civil penalties should advance in severity according to the length of time money is withheld, and according to the effort required to produce payment by the taxpayer. ${ }^{2}$ On the other hand, penalties should not be so severe as needlessly to penalize taxpayers who make honest errors, nor so lenient that they represent merely a small rate of interest on unpaid tax so long as the taxpayer can succeed in withholding payment.

Criminal penalties are threats of more dire consequences than the mere payment of additional money, although they serve as a deterrent in the same manner that civil penalties do. In practice criminal penalties can be enforced only against the most flagrant violations. Even then, unless public opinion is thoroughly aroused, their attempted enforcement is an ineffective means of compelling compliance. Judges and juries are reluctant to see criminal tendencies in so popular a pastime as outwitting the tax collector, and the doctrine of "reasonable doubt" presents a welcome exit for their use. ${ }^{3}$

Penalties, civil or criminal, are of little avail against the determined evader. A taxpayer who will not pay his tax will likewise not pay an additional penalty without compulsion. And the inadequacies of the criminal law are glaring. While no respectable tax law should be without civil and criminal penalties, other more potent tools are also called for.

A common device for the enforcement of state motor fuel, liquor and cigarette

${ }^{3}$ The Illinois Retailers' Occupation Tax Act, for example, provides for a ten per cent penalty upon failure to make payments on time if payment is thereafter made prior to notice by the Department of Finance. If the Department is forced to determine the tax and make an assessment, the penalty is twenty-five per cent. Distinction is thus made between inadvertent non-compliance and willful failure to comply. Formerly, interest at the rate of one per cent per month was also charged, but the difficulty of computation led to repeal of this provision.

${ }^{3}$ The authors know of cases where taxpayers have openly refused to comply with the tax law by filing returns, have boasted publicly of their non-compliance, and have been acquitted by juries or assessed minimum fines by judges. In one instance a taxpayer operated for a period of years without payment of sales tax and after conviction by a jury was fined \$roo by the judge. In another, the taxpayer was sentenced to jail but released after a few days by order of the court "pending appeal," although the same taxpayer had theretofore appealed to the state supreme court on the same grounds and had lost. 
taxes is a requirement for a license, which may be revoked for non-payment of tax. Such a provision places in the administrator's hands a powerful weapon to enforce compliance if he uses reasonable diligence. While retail sales tax laws generally require licenses or certificates of registration, ${ }^{4}$ express provision is not commonly made for revocation of licenses for violation of their provisions. This condition is paradoxical, since the need for such stringent requirements would seem even greater in the case of such taxes than in the case of motor fuel, liquor and tobacco taxes. Retailers, on the whole, have less capital and are more irresponsible than the wholesalers or "distributors" from whom these latter taxes are ordinarily collected. The barriers to use of the licensing device in state sales tax laws would seem to be economic and political rather than legal.5 The typical retail merchant is the "little fellow" for whom legislatures have so much regard. To give tax administrators the power to put him out of business, even though adequate court review be assured, is repugnant; it is this which probably explains the lack in so many states of power to revoke licenses. ${ }^{6}$

A requirement that the taxpayer shall post a bond to guarantee payment of the proper tax is an effective protective device, in effect "insuring" the taxpayer's solvency. With reasonable diligence on the administrator's part, a bonding requirement solves the problem of uncollectible accounts, a problem which no other provision of law can effectively meet. Penalties, license revocations and other such devices are of no avail against insolvent taxpayers. Yet no retail sales tax law carries a mandatory provision for the posting of security; again economic and political barriers stand in the way. The premium on a tax bond is expensive ${ }^{7}$ and in many cases taxpayers are not in a position to obtain a satisfactory bond without posting collateral, which they do not have.

Some state retail sales tax laws attempt to solve the problem by requiring the

\footnotetext{
- The following states require licenses or certificates of registration in connection with their retail sales taxes: Alabama, Arizona, California, Colorado, Delaware, Illinois, Iowa, Kansas, Michigan, Mississippi, New Mexico, North Carolina, North Dakota, Ohio, Oklahoma, South Dakota, Utah, Washington and Wyoming. No license is required in Arkansas, Indiana and Missouri, and licenses are required only of importers by Louisiana.

EThe sovereign, having the power to tax, has the power to enforce collection of the tax whether it is collected from retailers, wholesalers or manufacturers. In Dept. of Finance v. Gandolfi, 375 Ill. 237, 239, 30 N. E. (2d) 737,738 (1940), commenting on the provision of the Retailers' Occupation 'Tax Act requiring a certificate of registration to be obtained by a retailer before engaging in business, the court said: "It is a well-recognized attribute of sovereign power to tax any occupation for the purpose of raising revenue, and to impose and collect the tax in the form of a license. (Price v. People, r93 Ill. rI4; Banta v. City of Chicago, $x 72$ id. 204). Defendants fail to recognize the distinction between enactments designed to supervise occupations under the police power, and administrative regulations intended to aid the enforcement of tax legislation. The power of the legislature to aid administration and collection of taxes by reasonable measures requiring license and imposing penalties is uniformly recognized. (People v. Werner, 364 Ill. 594; People v. Wilson Oil Co., id. 406; Citizens Water Works v. Hughes, 362 Ill. I36; People v. Chicago, Burlington and Quincy Railroad Co., 306 id. 62; Chicago, Rock Island and Pacific Railway Co. v. People, 217 id. I64.)"

${ }^{6}$ Little difficulty was encountered in adding a licensing provision, with power to revoke, to the Illinois Retailers' Occupation Tax Act. Ill. Laws I935, p. I201, now Ilz. Rev. StAt. (Bar Ass'n Ed., 1939) c. $120, \$ \$ 44 \mathrm{Ia}, 44 \mathrm{Ib}$. But the fear of political repercussions was so great that the administration then in power never exercised the right which the legislature gave to it.

${ }^{7}$ Tax bond premiums range from $\$ 12$ to $\$ 18$ annually per thousand.
} 
posting of a bond only when the administrator has reason to believe that such action is necessary to avoid default. ${ }^{8}$ Similar provisions are also found in some state tobacco tax laws, although here a few states require mandatory bonds. ${ }^{9}$ Bonding requirements are much more common in the case of motor fuel and liquor taxes. The first type of tax is the oldest consumption excise, and experience in connection with it has demonstrated the wisdom of providing insurance that the state receive its revenues. The liquor business, only recently readmitted to legitimacy, is in no position to bring political pressure to bear. And both motor fuel and liquor taxes are typically collected from a few wholesalers or distributors, which makes it easier for legislatures to impose restrictions. ${ }^{10}$

States have sought to protect tax revenues by enacting statutory liens upon the property of taxpayers who may become delinquent. Where proper posting of security is required, liens are not necessary; but if this cannot be accomplished, a lien may be the "next best" device. Liens are especially useful in forcing payment by taxpayers who must maintain their credit with wholesale suppliers. Wholesalers will not sell merchandise to a retailer on open account if the property is subject to seizure by the state for unpaid tax liability. For this reason, a lien constitutes a powerful instrument to enforce payment in any case where the retailer is dependent upon wholesalers' credit to continue in business. ${ }^{11}$

Lien laws differ primarily in their provisions for the time at which the lien arises. The Michigan sales tax law, for example, states that the lien arises as soon as the tax is due, which is when the sale is made. ${ }^{12}$ At the other extreme are a few states which declare that the lien does not attach until after notice to the taxpayer of final assessment, and after opportunity for judicial review. Most lien laws fall between these limits, the typical provision being that the lien attaches when the tax is due to be paid by the retailer and after notice of assessment. ${ }^{13}$

\footnotetext{
${ }^{8}$ Alabama, California, Kansas, Michigan, North Dakota, Utah and Wyoming provide for "discretionary" bonding in their retail sales tax laws. "Discretionary" bonds have the weakness that the administrator often will not be in a position to know of whom to require security until default is made, and thus have the shortcoming of "locking the door after the horse is stolen." There is also the legal question of the legislature's power to delegate this kind of authority to an administrative officer. In People v. Federal Surety Co., 336 Ill. 472, 475, 168 N. E. 40I, 402 (1929), the Illinois supreme court invalidated a law permitting the Secretary of State to fix the penalty of a bond, saying: "The Legislature cannot delegate arbitrary power to any executive officer to say that under the same circumstances one rule of law shall apply to one or some individuals and another rule to others."

${ }^{\circ}$ New York and Iowa require bonds to be posted by all distributors under their cigarette tax laws. Ohio, Massachusetts, and some other states have discretionary bonding provisions. Even in tobacco tax laws, bonding requirements are not common.

${ }_{10}$ Tobacco taxes are also collected from "distributors," but, actually, a tobacco distributor may be a retailer who buys directly from the manufacturer outside the state. The result is that far more taxpayers are concerned directly with a tobacco tax than with a motor fuel or liquor tax.

${ }^{11}$ There is some question whether the interest of a purchaser under a conditional sales contract is subject to a tax lien. In General Motors Acceptance Corp. v. Whitefield, 62 S. D. 415, 420, 253 N. W. 450, 453 (1934), the court held that the interest of the conditional buyer in a chattel is not his personal property so as to permit seizure under distraint for taxes. The court said: "... such lien could not attach to property rights which had always belonged to the appellant [creditor], with which the appellant had never parted, and which Bessler [taxpayer] had never owned, although he might have a contract right to obmin them."

${ }^{12}$ Mich. Pub. Acts 1939, No. 3×3, now Mrch. Stat. ANs. (Henderson, Supp. 1940) $\$ 7.534$.

${ }^{23}$ Lien provisions are in all but three state sales tax laws, being omitted by Louisiana (which provides
} 
While the purpose of a lien is to preserve for the state property of the taxpayer out of which payment can be secured, by preventing his disposition of such property prior to discharge of the tax liability, security for the state must be carefully balanced against the evil of undue interference with normal business relationships. The language of some state lien laws would seem to indicate that a lien could attach "on suspicion"; when the tax authority feels that the taxpayer's full liability has not been declared and paid, it apparently may impose a lien immediately, without hearing. ${ }^{14}$ It is questionable whether sufficient care can be exercised by a tax administrator to prevent such a device from working hardship on innocent purchasers of a retailer's property, or from seriously interfering with the normal course of a taxpayer's business by tying up his assets while proceedings are under way to determine whether any liability actually exists. The dilemma between non-interference with normal business practices and protection to the state becomes clear. Yet, if the state is not in a position immediately to set up a lien on a taxpayer's property, and must wait until he is given a hearing by the administrative body and the courts, unscrupulous taxpayers are afforded an opportunity to dispose of their property and thus defeat the state's rights. 15

Probably the best compromise in this dilemma is to permit the lien to attach only after a hearing in which the administrative body has established that an amount of tax liability is due. This permits the administrator, by expediting the proceedings, to shorten the time during which a dishonest taxpayer may dispose of his assets to defeat the lien, and yet affords the taxpayer a hearing before his assets are impounded. The taxpayer, of course, is not deprived of his right to a review by the courts after an adverse decision by the administrative body, but the fact that the lien exists pending such review constitutes an incentive for him to obtain a quick trial rather than to attempt to draw out the proceedings in the hope of delaying payment. ${ }^{16}$

In Illinois, an enforcement device, lying outside of any taxing statute has been used to garner "uncollectible" accounts. Under the Illinois Corporation Act a corporation which violates "any State law" is subject to receivership upon application to a court by the Secretary of State on complaint of the injured party. ${ }^{17}$ The Department of Finance has, upon occasion, petitioned for appointment of a receiver to take over the assets and business of delinquent corporations. This procedure was adopted

for a lien only upon importers), Ohio and Oklahoma. The Arizona lien operates only against the purchaser of a business owing sales tax. ARJz. Code ANN. (1939) \$73-r317.

${ }^{14}$ E.g., CaL. Gen. Laws (Deering, Supp. 1933) act 8493 , \$26.

${ }^{25}$ While, theoretically, property disposed of fraudulently to defeat a lien may be made subject thereto, actually it is next to impossible to prove fraud. Assets can be transferred to a new corporation or chattel mortgages executed in favor of interested third parties, leaving the state an empty shell with no real recourse.

${ }^{10}$ At the time the lien sections of the Illinois Retailers' Occupation Tax Act were added in I937, an effort was made to obtain the kind of provision here recommended. Fear on the part of some legislators that retailers' property might be arbitrarily "tied up" caused its rejection, there being adopted in its place a provision allowing the lien to attach only after all court proceedings for review have terminated, or the opportunity therefor has expired. Ill. Laws, 1939, p. 880, now ILL. Rev. Stat. (Bar Ass'n Ed., 1939) c. $120, \$ 444 a$.

${ }^{17}$ ILl. Rev. StAt. (Bar Ass'n Ed., 1939) c. 32, \$157.82. 
for use against corporations which saw fit to use "devices" to make their assets execution-proof, or against corporations whose assets were subject to prior liens, or which for any other reason could not be reached by ordinary procedures. Ordinarily, upon appointment of the receiver the corporation officials have hastily made arrangements to pay up back liability. In some instances, the Department's receiver has actually carried on the business for a period of time, applying all receipts and free assets toward payment of the tax delinquency.

Many states have enacted provisions limiting the period during which unassessed taxes are legally collectible. Statutes of limitations are not ordinarily considered as collection devices, but, paradoxically, such provisions may actually aid enforcement. In the absence of some limitation on the period for which the state can assess past liability, it is necessary, when audits of taxpayers are made, to check back to the effective date of the tax, if the taxpayer has been in business that long. Audits for so long a period are poor administrative devices. Taxpayer resistance in these instances is great, and courts are often reluctant to enforce collection of taxes that have lain dormant for long periods.

But this is only part of the problem raised by long periods of taxpayer liability. It is not necessary, and never has been, to enforce a tax against every taxpayer. To impel payment by a taxpayer, it is merely necessary that he be made to know that his delinquency will be quickly ascertained and that action will be taken against him. A statute of limitations, by limiting the period of business operations which must be audited, allows a given force of auditors to perform more individual audits each year. This means that a larger proportion of taxpayers can be audited every year, thus increasing the risk for any one taxpayer that his delinquencies will be detected. When taxpayers are aware of the risk of detection, they will be impelled to pay their just liability. The physical impossibility of auditing the greater number of retailers under a sales tax makes a statute of limitations much more important in this instance than in the case of motor fuel, liquor and cigarette taxes, where the number of taxpayers is typically smaller and financial responsibility greater.

In drafting a statute of limitations, the selection of the period after which unassessed taxes are not recoverable is the major problem. The period must strike an empirical balance between one sufficiently long to prevent important amounts of liability from going unpaid and one short enough to relieve auditing departments of the burden of checking back for many years. ${ }^{18}$

The device of the informational return is common in implementing enforcement of state consumption excise taxes. Informational returns may or may not be explicitly provided by law. Motor fuel, cigarette and liquor tax laws often provide that carriers transporting the taxed articles into the taxing state shall keep records of goods so transported and make them available to the taxing authority. Under such laws, also, it is often required that dealers receiving the taxed articles so keep their

${ }^{18}$ After study of its own situation, the Illinois State Department of Finance requested of the Illinois General Assembly a three-year limit, which became law in I939. Ilz. Rev. Stat. (Bar Ass'n Ed., 1939) c. $120, \$ 443$. 
books that the taxing authority can trace the taxed commodity back to the distributor who is liable for the tax. Even in the absence of specific provision in the law, however, tax administrators can use informational returns if the law gives the power to subpoena relevant papers and documents or other information. Thus, in enforcing sales taxes where retailers either have no books or there is some reason to question the veracity of a taxpayer's accounts, a check of the wholesalers from whom the retailer buys will often build up a case against the retailer. Indeed, this is sometimes the only way in which anything approaching the true liability of some retailers can be discovered.

It would undoubtedly be desirable, viewed strictly from the standpoint of tax enforcement, to require that every party to a taxable transaction make periodic reports of such transactions. In other words, if the tax is imposed upon a distributor, it would be helpful if not only he, but the retailers to whom he sells, reported monthly to the taxing authority all their transactions concerning the taxed commodity. For example, the distributor of cigarettes upon whom the tax is laid reports the sale of a certain number of cases of cigarettes to a retailer. The retailer in turn is required to report receipt of the cigarettes. A discrepancy in the reports immediately throws suspicion upon the distributor. Such a procedure is theoretically possible under any consumption excise tax law, including a retail sales tax, even though the liability here is upon the retailer rather than the wholesaler or manufacturer. Nevertheless, such a system imposes burdens upon so many persons other than those legally liable for the tax that it is found in few state tax laws.

An important method of aiding in enforcement of liquor taxes is represented by exchange between states of information concerning liquor shipments out of, and into them. Liquor shipped from one state to another is not taxable by the exporting state under the commerce clause. ${ }^{18}$ In order to protect themselves against diversion of liquor reported to be shipped outside the state, most of the states imposing liquor taxes have arranged to notify the state into which liquor is reported shipped of such shipment, naming the amount and kind of liquor and the consignee. The state receiving the information then notifies the exporting state when the consignee reports receipt of the liquor. Such a system, of course, depends entirely on the degree of cooperation existing between the states. A state which does not participate, or cooperates only perfunctorily, endangers the revenues not only of exporting states, but its own as well. ${ }^{20}$

\section{"Economic" Factors Affecting the Collection of Consumer Taxes}

Probably the most important single factor determining whether or not a tax will be completely collected is the adequacy and quality of the field staff available to

${ }^{10}$ Cf. Adams Mfg. Co. v. Storen, 304 U. S. 307 (1938); Crew Levick Co. v. Pennsylvania, 245 U. S. 292 ( 1917 ).

${ }^{20}$ The so-called "dry" states have been found to be the worst offenders. With no revenues at stake, these states have taken no action even when notified of shipments of liquor into their jurisdictions. As a result, distributors in exporting states can with impunity report sales to bootleggers in dry states, thus escaping the exporting state's tax. That state, in turn, has no proof that the liquor allegedly exported ever left its jurisdiction. 
enforce it. ${ }^{21}$ Legislators and courts may control legal tools available to the administrator, but personnel is directly responsible to him and he is responsible for the results obtained by his staff.

Mentioned above was the fact that a tax does not have to be enforced against every taxpayer. Much more important than the liability uncovered directly by auditors and investigators is the amount "scared in" by taxpayer knowledge that the law is being enforced. Statistically, these two sources of additional liability are difficult to distinguish, and it is unimportant that they cannot be. It is the amount of additional liability paid both as direct and indirect result of the employment of additional field workers that matters to the tax administrator.

Statistical study of sales tax collections by the various states shows a striking correlation between the number of retail stores per auditor and investigator and the proportion of sales tax not collected; the larger the number of stores per field worker, the larger the share of the tax unpaid. The following table compares the adequacy of collections with the relative enforcement staff in each of the five most populous states levying retail sales taxes.

TABLE I

Estimated Percentage of Tax Lost Compared with Numbers of Retail Stores in Five Populous Sales Tax States ${ }^{22}$

\begin{tabular}{|c|c|c|c|c|c|c|c|}
\hline State & $\begin{array}{l}\text { Adjusted } \\
\text { Taxable } \\
\text { Sales I940 } \\
(000)\end{array}$ & $\begin{array}{l}\text { Sales } \\
\text { Tax } \\
\text { Rate }\end{array}$ & $\begin{array}{l}\text { Potential Yield } \\
\text { of State Tax } \\
\text { Rate times Adj. } \\
\text { Retail Sales } \\
(000)\end{array}$ & $\begin{array}{l}\text { Actual } \\
\text { Collec- } \\
\text { tions } \\
\text { I940 } \\
(000)\end{array}$ & $\begin{array}{l}\text { Tax } \\
\text { Lost } \\
\text { I940 } \\
(000)\end{array}$ & $\begin{array}{l}\text { Per } \\
\text { cent } \\
\text { Lost }\end{array}$ & $\begin{array}{l}\text { Retail } \\
\text { Stores } \\
\text { Per } \\
\text { Field } \\
\text { Worker }\end{array}$ \\
\hline California & $\$ 3,444,033$ & $3 \%$ & $\$ 103,320$ & $\$ 102,939$ & $\$ 3^{8 I}$ & $0.4 \%$ & 182.5 \\
\hline Illinois .. & $3,508,000$ & $3 \%$ & 105,240 & 97,8 ro & 7,430 & $7.0 \%$ & 259.2 \\
\hline Michigan . & $2,362,200$ & $3 \%$ & 70,866 & 66,784 & 4,082 & $5.8 \%$ & 285.6 \\
\hline Missouri & $x, 398.93 x$ & $2 \%$ & 27,979 & 24,437 & 3,542 & $12.7 \%$ & 483.6 \\
\hline Ohio ........ & $2,009,357$ & $3 \%$ & 60,281 & 52,975 & 7,306 & $\mathrm{I} 2 . \mathrm{I} \%$ & $4^{87} 7 \cdot 1$ \\
\hline
\end{tabular}

a Retail sales reported by the Census Bureau for each state were adjusted to obtain a figure representing taxable sales in each state.

${ }^{21}$ An adequate "field staff," which includes auditors, investigators, inspectors, etc., is assumed to have the necessary supporting office personnel in the form of supervisors, clerks, hearing officers, and the like. But it is the field staff which is the "spearhead" of tax collection activity. Other employees, while necessary, contribute only indirectly to tax enforcement.

${ }_{22}$ The following calculation for Illinois indicates the manner in which the figures used in the table were computed:

\section{IxxinoIs}

Collections: I940 Sales

Deduct Tax Reflected in Retailers' Occupation Tax But Not in Census:

$\$ 97,809,705$

Wholesalers and Jobbers......................... $\$ 5,553,795$

Manufacturers and Producers.........................

Garages and Repair Shops...................... r,734,910

Hotels . . . . . . . . . . . . .

Barber and Beauty Shops.............................. 80,508

Shoe and Harness Repair......................... 69,179

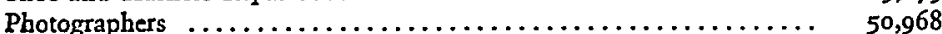


In these figures lies strong evidence of the necessity for adequate personnel. The addition of field employees sufficient to bring the other four states up to the scale employed by California, which enjoys practically complete collections, would obviously yield enormous dividends. In the case of Illinois it is estimated that expenditure of $\$ 554,000$ a year to hire the 177 additional auditors, investigators and supporting office personnel necessary to equal the California level, would add approximately $\$ 7,000,000$ a year to Illinois sales tax collections.

It goes without saying that mere number of personnel does not insure a successful tax department. The fact that complete retail sales and other consumption excise tax collections seem to go hand in hand with an adequate number of people engaged in tax enforcement is far from meaning that qualifications of employees are unimportant. The seemingly close connection between completeness of collections and the number of field employees (supported by proper office personnel) only indicates that in the states reviewed the average degree of efficiency per employee is at a high level, and about the same in each state.

Disposal of field staff in accordance with economic realities is certain to have a favorable effect on the collection of consumer excise taxes. By concentrating the efforts of auditors and investigators in certain areas, both economic and geographic, liability discovered and "scared in" by them can be substantially increased. An economic area may be a classification or sub-classification of business, such as automobile dealers or taverns under a retail sales tax, or may be all businesses of a certain size which are subject to a tax. Geographic areas, of course, may be all businesses in a county or city, or certain types of businesses therein.

Morticians and Funeral Directors.................. 299,480

Bowling and Billiards..................... 134,827

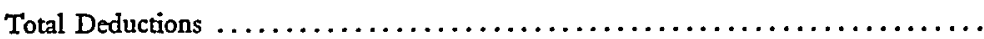

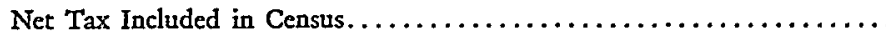

$\frac{\$ \quad 16,472,528}{\$ 81,337,177}$

Add Estimated 'Tax Not Reflected in Retailers' Occupation

Tax But Included in Census:

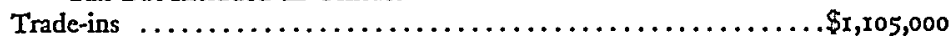

Illinois Motor Fuel Tax-(not part of sales tax base)......... 1,386,000

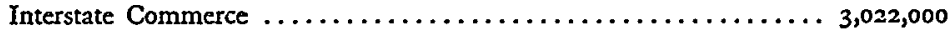

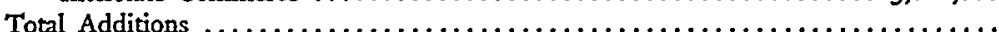

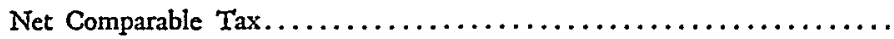

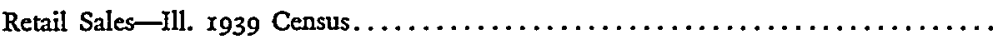

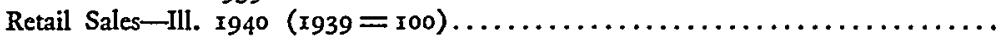

Estimated Retail Sales Reported by Census-r940...................

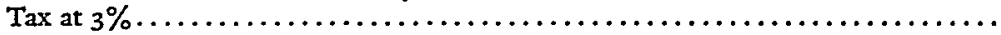

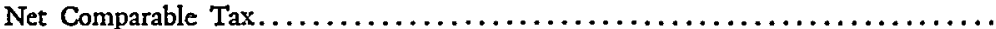

Collection Ratio

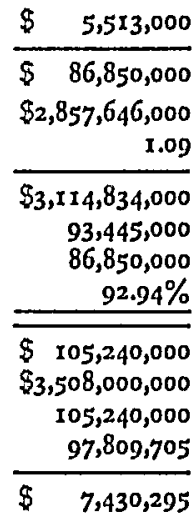

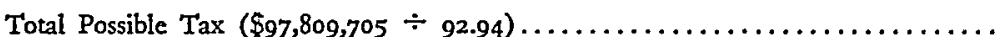

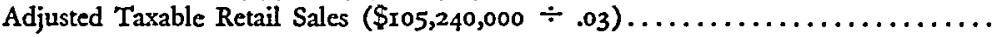

3\% Tax Should Yield.

Actual Tax Collected.$\ldots \ldots \ldots \ldots \ldots \ldots \ldots \ldots \ldots \ldots \ldots \ldots \ldots \ldots \ldots \ldots$

TAX LosT, I940.

$\$ 7,430,295$ 
The tax administrator can discover a great deal about the most fruitful areas for audit and investigation from material readily available to him. Valuable information can be obtained from a study of the results of past audits and investigations. Other and more technical knowledge can be gotten from statistical analysis of taxpayers' returns over a period of years. And there is a good deal of information of the "horse sense" variety knocking around inside the heads of field workers which can profitably be assembled by the tax administrator.

One of the most immediate facts disclosed by a study of the results of audits and investigations of the objects of a retail sales tax will probably be that concentration on the larger taxpayers offers very lucrative returns, both in amounts directly uncovered by audit and the amounts "scared in" from other large taxpayers. A study of sales tax audits made by the Illinois Department of Finance disclosed that the liability discovered in auditing the smallest taxpayer (under $\$ 5.00$ monthly) did not justify the cost of the audits, whereas the Department on the average assessed eleven and one-half times as much as the cost of the audits in the case of taxpayers with tax liability exceeding $\$ x, 000$ per month, not to mention the additional amounts secured indirectly by knowledge that audits of large businesses were being made.

Statistical analysis of returns made in past years will produce a great variety of information which can best be used in connection with a study of the results of past audits. Occasionally such analysis suggests new fields for concentration. A study of Retailers' Occupation Tax returns in Illinois ${ }^{23}$ disclosed very large variations in the proportion of total tax liability collected for various kinds of retailers, ranging from over roo per cent ${ }^{24}$ to as low as $\sigma_{5}$ per cent. The same study disclosed geographic variation in relative completeness of collections. This geographic variation was found largely traceable to differences in the economic development of the several areas of the state. Comparable collection ratios were discovered for areas homogeneous with reference to location, purchasing power and degree of urbanization. Analysis by size of monthly tax returns confirmed the study of audits and investigation results in that the largest total delinquencies discoverable, as opposed to proportion of delinquency discoverable, were concentrated in the large retail businesses.

Intelligent use of these various kinds of information will instruct the administrator in the proper disposal of his field staff. As was mentioned earlier, he should be guided by the largest dollar volume of liability which can be discovered and "scared in" by a given personnel. There are too many variables to be considered to permit of nice mathematical computation of the optimum disposal of field staff, but very intelligent approximation of the best alternative combination can be made with the information above outlined.

The amount and structure of exemptions from the tax base are important factors affecting collection and enforcement of consumer taxes. Economically, exemptions

${ }^{33}$ Ill. Dep't of Finance, Completeness of Collections under the Retailers Occutpation Tax Act (MS).

${ }^{26}$ In interpreting collection ratios, it should be kepr in mind that such a ratio is a statistical concept which may sometimes exceed xoo per cent. A familiar example of such a concept is the percentage of steel mill capacity, which of late has generally exceeded roo per cent. 
include every tax-free event which is connected with taxable events. Whether implicit or explicit, they result, of course, in.a direct loss of revenue. Administratively this is not a problem, however, for exemptions are a matter of law. ${ }^{25}$ It is the indirect loss of revenue due to the existence of exemptions which concerns the administrator. Exemptions produce indirect losses of revenue because they offer taxpayers the opportunity to report their transactions as taking place in the tax-free area. Dishonest taxpayers have an incentive to report as tax-free, transactions which in fact are not. Honest taxpayers are inclined to give themselves the benefit of any doubt. The result to be expected is under-reporting of taxable transactions, especially in "mixed" businesses having both taxable and non-taxable sales.

It would likewise be expected that the absence of a tax on "wholesale sales" would lead to incomplete reporting. Where sales for resale are not taxable, retailers, in spite of contrary provisions in the laws, are in the habit of reporting only such of their sales as they deem taxable, rather than reporting all sales and claiming exemption for some of them. The implicit exemption of such sales thus has the economic effect of actual exemption. Taxation of sales for resale, even at a nominal rate, prevents the non-reporting of these events. Such reporting enables the tax authority to trace sales through the retail stage on the basis of wholesale tax data, and thus to detect evasions.

This reasoning seems to be borne out by available statistics. According to a study of the subject, those states with relatively broad sales tax bases show consistently better collection effectiveness than the narrow-tax-base states. ${ }^{28}$ Noteworthy is the fact that taxation of sales for resale has a most pronounced effect on collection effectiveness.

Economically, high tax rates adversely affect collection effectiveness in two ways. One is, of course, an increase of taxpayer resistance as tax rates increase, making more administrative effort necessary for the collection of a given proportion of tax liability as the gains from successful evasion constitute greater incentives. The other is the flow of entrepreneurial effort away from enterprises subject to heavy tax rates as the tax raises the price of the taxed good and thus reduces demand for it. These two effects are statistically difficult to separate.

If it were possible to know what proportion of the observed drop in collection efficiency owing to higher tax rates can be ascribed to increased taxpayer resistance, estimates could be made of the increase in enforcement personnel and other steps economically best suited to counteract declining collection effectiveness as the tax rate rises. But until the effect of increased taxpayer resistance can be separated from that of decreased sales due to increased price, it does not appear safe to make recommen-

\footnotetext{
${ }^{25}$ Express and implied exemptions are treated by Frampton and Smith, Commodities and Transactions Exempt from Consumption Taxes; Conlon, Express or Implied Exclusions from Constumption ExcisesTypes of Consumers, both infra this issue.

${ }^{26}$ Lack of space prevents adequate explanation here of this conclusion. Readers who are interested are referred to a forthcoming monograph, Toward Effective Tax Collections, by J. W. Huston and Thomas Lee Smith.
} 
dations regarding steps to sustain the completeness of collections against the impact of rate increases. ${ }^{27}$

Tax stamps are commonly used in connection with taxes on liquor and tobacco. Those states taxing tobacco in any form have with one exception employed them. ${ }^{28}$ Of the twenty-eight states which license and tax the sale of liquor, only four do not employ stamps as evidence of payment of tax..$^{29}$ Stamps are not suited to motor fuel taxes, and only one state, Ohio, uses them in connection with a retail sales tax law. ${ }^{30}$ Tax stamps on liquor and tobacco are economic devices to the extent they advertise tax payment, their absence causing public notice of evasion. Requirement that taxpaid goods bear stamps as evidence of payment of tax is also a legal method to permit the seizure of contraband. The enforcement effect of stamp provisions lies in the power to confiscate unstamped goods, the seizure provision having the effect of a lien on the contraband. ${ }^{31}$

The fact that some states evidently do not consider the stamp method the only way to enforce excise taxes on liquor and tobacco makes the method open to some question. The tax stamp plan is relatively expensive; the stamps themselves are costly, often representing about as large a share of the cost of enforcement as all other items put together. ${ }^{32}$ Discounts are very generally granted wholesalers for affixing the stamps, further reducing net revenue. The costs of examining the goods to detect contraband, of course, are a further element in the administrative expense of the stamp plan.

Statistically, the verdict on the necessity for stamps is mixed. Massachusetts seems

\footnotetext{
${ }^{27}$ Logically, it would be expected that increased taxpayer resistance would make each succeeding increment of liability more difficult to collect as the tax rate was increased. By that token, the collection of a given proportion of liability would be relatively increasingly expensive as the tax rate increased. To judge accurately the optimum addition to staff to counteract this effect, the administrator would have to be able to estimate the marginal liability uncovered (directly or "scared in") at each level of tax. Properly speaking, only a three-dimensional diagram could accurately represent the facts.

Martin, Distribution of the Consumption Tax Load, supra this issue, presents data on the effect of taxation on the demand for goods, especially those sold at a customary price.

${ }^{28}$ Ḿassachusetts does not employ tax stamps, but uses a system of monthly reports such as is general under retail sales taxes.

${ }_{20}$ Connecticut, Massachusetts, New Jersey and New York.

${ }^{30}$ The Ohio stamp plan is not properly a legal device to aid enforcement. It is discussed infra, in connection with public and taxpayer relations as an aid in enforcement.

${ }^{31}$ In Ploch v. City of St. Louis, 345 Mo. 1069, I079, 138 S. W. (2d) 1020, 1025 (I940), the court said, with reference to plaintiff's claim that the seizure provisions of the St. Louis cigarette tax violated the search and seizure clause of the state constitution: "It is clear that it was not intended to declare a forfeiture of title to unstamped cigarettes, for it is provided that the balance of the proceeds of the sale, after the payment of the tax, penalty and costs, must be paid to the merchant or person who was in possession of the unstamped cigarettes. In effect, under said section, the tax is a lien on the cigarettes which may be sold, as therein provided, to enforce payment of the tax. 'The mode of levying and collecting taxes is a matter confided to the legislative power, and such laws are "laws of the land." [DeOrman v. Williams, 93 Mo. $158,163,5$ S. W. 904 , Sec. 9915, R. S. 1929.]" Even if no provision is made to pay any balance remaining after settling the state's claim, the same would still apply, for the penalty could be considered as consisting of the proceeds of the sale. It is clear, further, that seizure without a warrant is no violation of right. Any representative of the taxing authority who sees a violation take place may arrest the violator without warrant. However, he may not, without a warrant, search for contraband against the will of a suspected violator.

${ }^{32}$ In the fiscal year $1940,4^{6.2}$ per cent of the cost of administering the Illinois Liquor Tax was due to the purchase of tax stamps.
} 
to be doing a good job of enforcement with its cigarette tax. ${ }^{33}$ But none of the four states not employing stamps to enforce their liquor taxes ranked above the median in collection effectiveness as measured by a current study. ${ }^{34}$ Until many other states attempt to enforce their cigarette and liquor taxes without stamps and the results can be adequately compared, it must be concluded that tax stamps are probably the most effective method of enforcing these taxes.

\section{Public and Taxpayer Relations as a Factor in Effective Tax Collections}

Relations of the tax authority with the public and the objects of the tax can have considerable effect on the cost of collecting a given amount of liability. Public acquiescence in a tax, and unwillingnes to see it evaded, may favorably affect collections. Public knowledge of the need for a tax and of the use of its proceeds can create public sentiment in its favor. Similarly, taxpayer knowledge of enforcement methods and the regard in which taxpayers hold the administrative personnel may appreciably affect collection costs.

Public funds have been spent in some jurisdictions to gain public and taxpayer good will. The Illinois Division of Department Reports has been used to issue press releases regarding the operations of Illinois taxes, the disposition of their proceeds, and the need for the funds they bring to the state treasury. Research divisions of tax departments have sometimes issued pamphlets and other publications relating to the disposition of tax funds. ${ }^{35}$ The taxpayer himself has been the direct object of some such material, frequently printed on the back of the forms provided for tax returns. ${ }^{36}$

Securing taxpayer cooperation has probably been considered more important than obtaining public acquiescence to a tax. One method of obtaining this cooperation has been the granting of discounts from tax liability, generally on the grounds that the taxpayer is put to some expense in collecting the tax. This practice is most common under tobacco tax laws, where discounts allowed for the cost of affixing stamps range as high as ten per cent in several states, although more usual ranges are between five and seven per cent. Discounts to distributors for collecting motor fuel taxes vary from zero in Florida, New Jersey, Rhode Island and Wyoming to four per cent in South Dakota, the more usual range being in the neighborhood of two per cent. A few states grant discounts in connection with their liquor and retail sales taxes. ${ }^{37}$

\footnotetext{
${ }^{33}$ By any of several measures of the Massachusetts share of the total number of cigarettes consumed in the United States, Massachusetts ranks high in collection effectiveness. The most reliable indices indicate that probably only one or two states do a better job.

${ }^{34}$ The reader is again referred to the forthcoming study cited supra note 26.

${ }^{35}$ Cf. Huston and Berriman, The A-B-C of Illinois State Finance (2d ed. 1940); also Ill. Dep't of Finance, Twenty-third Ann. Rep. (1940).

${ }^{30}$ Compare the forms for Retailers' Occupation Tax returns in Illinois.

${ }^{37}$ Discounts for affixing liquor tax stamps are granted by Kentucky $(3 \%)$ and Ohio $(5 \%)$. Mississippi (dry) grants $5 \%$ on beer stamps. Sales tax discounts are: Alabama, $3 \%$; Louisiana, $5 \%$; Missouri, $3 \%$; Ohio $3 \%$; Oklahoma, $3 \%$. Michigan exempts the first \$50 of tax liability and Indiana exempts from taxation the first $\$ 3,000$ of gross receipts. Compensation for retailers is indirectly provided in some states by statutory establishment of brackets for payment of tax. West Virginia, for instance, under its two per cent sales tax requires I cent to be collected on sales ranging from 6 cents to 50 cents and 2 cents on sales
} 
There can be little doubt that affixing stamps to cigarettes or other tobacco products is a cause of added expense to tobacco distributors. There are probably some bookkeeping expenses connected with the payment of motor fuel taxes. At the same time, there does not seem to be any legal necessity for granting discounts. ${ }^{38}$ The duty of affixing stamps or collecting the tax from consumers is imposed by law as much as is the taxpayer's duty of paying the tax. It is clear, then, that discounts have been used as a concession to distributors to obtain their cooperation.

Whether or not the ideal tax law should contain discount provisions is open to question. It has been contended that business practices in the wholesale cigarette business make it impossible to shift the cost of affixing stamps on to retailers. ${ }^{39}$ The writers are not aware of any similar claim for discounts in the case of motor fuel and liquor taxes. Whether desirable or not, the rates of some of the discounts now in effect are clearly "out of line" with the added cost imposed. This fact can be established by reference to the provision in a good many states for different rates of discount according to the quantity of stamps purchased at one time. Georgia, for instance, grants a three per cent discount on cigarette tax stamp sales in blocks of $\$ 100$ to $\$ 200$, and a discount of ten per cent on sales of stamps in blocks of more than \$200. The cost of affixing stamps would be expected, however, to fall as the number affixed rose, rather than to increase. ${ }^{40}$

An inexpensive way of creating, if not taxpayer good will, at least taxpayer acquiescence is the promulgation of reasonable and practical rules and interpretations of tax laws. ${ }^{41}$ The taxpayer who believes that the rulings division is taking an intelligent and sympathetic interest in his problems may be mollified, even if it is held that his transactions are taxable. Willingness to make practical and workable compromises within the law can often prevent litigation and make available substantial amounts of liability which otherwise would be expensive or impossible to collect. An illustration of this can be found in the recent experience of the Illinois State Department of Finance. The Department was faced with the question of whether sales of

of $5 \mathrm{I}$ cents to $\$ \mathrm{I} .00$. This would clearly yield more than the two per cent of gross receipt the retailer must pay.

${ }^{38}$ Cf. Pierce Oil Corp. v. Hopkins, 264 U. S. 137 (I924); Texas Co. v. State, 3 I Ariz. 485, 254 Pac. ro6o (r927); Standard Oil Co. v. Brodie, 53 Ark. II4, 239 S. W. 753 (I922).

${ }^{30}$ In a recent hearing before the Illinois Department of Finance regarding the granting of discounts in connection with a projected cigarette tax in Illinois, cigarette wholesalers were in complete agreement that the cost of affixing stamps (which they estimated at over $5 \%$ of the cost of the stamps) could not be shifted to retailers. Economists would argue, of course, that there is no reason why such costs cannot be shifted, at least to the extent of the lowest cost of affixing stamps enjoyed by any wholesaler. No valid argument was advanced why the "laws" of partial equilibrium theory should be suspended for cigarette jobbers.

${ }^{20} \mathrm{~A}$ similar view on rates of discount now allowed is expressed in Ratchford, The Measure of Consumption Taxes, infra this issue.

"Not all tax administrators are of this opinion. Henry F. Long, Commissioner of Corporations and Taxation of the State of Massachusetts, recently stated in regard to rules and regulations: ". . I not only do not have any, but I do not believe in them as they have a habic of springing up and hitting you in the face when you least want them or expect them." Letter to Supervisor of Rules and Regulations, Illinois Retailers' Occupation Tax Division, April 28, I94I. 'This probably accurately reflects the attitude of most administrators, but inconvenience to the administrator must be weighed against the desire of the taxpayer to know where he stands. 
baby chicks by commercial hatcheries were sales for resale or sales to consumers. Only the latter are deemed taxable under the Illinois Retailers' Occupation Tax Act. Hatcherymen protested bitterly against paying the tax, pointing out that many of their purchasers raised the chicks for resale as pullets.

In order to make a fair ruling, the Department distributed over a thousand questionnaires to farmers throughout the state; replies were received from approximately one-half of the recipients. From this sample it was estimated that about seventy-five per cent of baby chicks purchased by farmers are resold. A rule was therefore promulgated to the effect that "hatcherymen will be liable for tax based on 25 per cent of their receipts from sale of baby chicks in all cases where it is not shown that a different percentage is applicable. Such percentage shall be considered prima facie correct." 42 This ruling satisfied hatcherymen as to its fairness, and tax is now collectible from them without difficulty. Serious misunderstanding with this class of taxpayers might have made all tax for which they are liable slow and expensive to collect.

Of the states imposing retail sales taxes, nine employ tokens as an aid to collection of the tax. In effect, sales tax tokens are fractional coinage, used to supply a medium of exchange of less than one cent. Denominations of one, two and five mills have been issued by the different states, and a three and one-third mill token has been proposed in Washington for use with its newly-enacted three per cent tax. Agitation for the adoption of sales tax tokens has generally come from the merchants, especially from those whose business is in large share made up of small sales. Fractional coinage allows merchants to collect tax from consumers on sales which could not be reached under the "bracket" system.

The shortcomings of sales tax tokens are largely due to the uses to which they are put by consumers, who have either found them unhandy and tossed them into the streets, or who have found too great utility in them when employed for other purposes, such as poker chips, washers for roofing nails or in place of Chinese money to decorate portieres. Lately a tax administrator has come out strongly against them, ${ }^{43}$ adding the excessive cost of the brass and aluminum from which they are usually made as an additional objection. This same statement points out, however, that there may be a place for them in states with low per capita wealth, where typical purchases are for small amounts, and collection of tax by the usual brackets difficult.

The Ohio sales tax law now incorporates a most interesting provision designed to secure public aid in enforcing the tax. ${ }^{44}$ Whenever a taxable sale is made under that act the vendor is required to give the vendee a tax stamp in the proper denomination, which he has suitably mutilated so as to constitute cancellation. A r939 amendment provides that the state will redeem cancelled tax stamps at three per cent of their face value and contribute the sum paid in redemption to any charity named by the

¿2Ill. Ret. Occ. Tax Reg. (I939) Rule No. 73.

${ }^{3}$ Dixwell L. Pierce, Secretary, State Board of Equalization, California, in a mimeographed release dated April I6, I94I, has argued against the adoption of tokens in California.

“ Ohio Laws I939, p. 40, now Orro GeN. Code (Throckmorton, I940) $\$ 5546-26$ a. 
purchaser submitting the cancelled stamps. Before installation of the incentive for retaining cancelled stamps, it is known that purchasers commonly discarded stamps on the premises of vendors, allowing their repeated use.

Sales tax tokens, and tax stamps such as those employed in Ohio, are both devices to secure public or taxpayer cooperation in collecting the tax. Tokens are a method of purchasing the good will of merchants so that they will be favorably disposed toward the tax and more willing to pay their just liability. The stamp-and-rebate scheme is likewise a method of purchasing cooperation, this time of the consumer. Neither tokens nor the Ohio stamps are, strictly speaking, legal devices for enforcing the tax. Liquor and cigarette tax stamps, of course, are legal enforcement devices, since the absence of tax stamps from liquor or cigarettes makes them liable for seizure. ${ }^{45}$ This is possible only because there is a physical connection between the taxed article and the tax stamps; the stamps are affixed to the article itself. Under the Ohio tax stamp plan there is no such necessary connection; the tax stamp is not attached to the article as proof that it was sold tax-paid. The only sanction created by the Ohio plan is economic; if a merchant does not furnish stamps so that purchasers can contribute to their favorite charity, the merchant may lose business. $\mathrm{He}$ is in no danger of having his merchandise seized because of absence of stamps, and in no danger of prosecution for failure to purchase the proper amount of stamps so long as he makes some sales to persons who are more interested in the reduced price thus possible than in contributing to charity. ${ }^{46}$

The principal objection to the Ohio stamp-and-rebate plan is its cost. Net sales and use tax paid by consumers in Ohio in I940 totalled $\$ 54,366,547$. Administrative' cost was $\$ 4,030,322$ for the same period, of which $\$ 843,939$ was for the redemption of stamps. Administration was thus seven and four-tenths per cent of net tax. ${ }^{47}$ Collections, at the same time, appear to have been at no higher level than in some states which rely on returns and auditors alone. ${ }^{48}$ Much more convincing evidence of the success of this plan is necessary before it can be recommended as a superior method of retail sales tax enforcement.

\footnotetext{
${ }^{45}$ See note $3 I$, supra.

${ }^{40} \mathrm{~A}$ merchant who fails to pay the Ohio tax is, of course, liable to be prosecuted if his delinquency is discovered by audit. Audits, however, are a distinct enforcement device quite apart from the tax stamp system.

${ }^{47}$ Cost of administering the Illinois Retailers' Occupation Tax, during the same year, was approximately two per cent.

${ }^{48}$ See the table at p. 513 , supra.
} 